\title{
PENGGUNAAN KAMUS DWIBAHASA SEBAGAI SUMBER BELAJAR DALAM PENGUASAAN KOSAKATA ARAB MAHASISWA FAKULTAS HUKUM UNIVERSITAS MUHAMMADIYAH MATARAM
}

\author{
Nasarudin \\ Universitas Muhammadiyah mataram \\ Nasarmtdn@gmail.com
}

\begin{abstract}
Abstrak
Kamus-kamus bahasa Arab istilah ilmu hukum seperti Mu'jam al-Qanun karya Syauqi Dhoyf digunakan dalam pembelajaran bahasa Arab di Fakultas Hukum Universitas Muhammadiyah Mataram sebagai sumber belajar dalam menguasai kosakata bahasa Arab dalam bidang ilmu hukum. Tujuan penelitian ini adalah menganalisis proses pembelajaran bahasa Arab menggunakan kamus sebagai sumber belajar dalam penguasaan kosakata Arab mahasiswa dan kendala-kendala yang dihadapi dosen dan mahassiwa Fakultas Hukum Universitas Muhammadiyah Mataram. Dan adapun metode penelitian ini menggunakan pendekatan kualitatif dengan jenis studi kasus dan dengan analisis data Miles \& Huberman terdiiri dari tiga langkah yaitu kondensasi data, paparan data dan penarikan kesimpulan. Dan adapun output peneletian adalah 1) Proses pembelajaran bahasa Arab menggunakan kamus sebagai sumber belajar dalam penguasaan kosakata Arab mahasiswa menekankan adanya interaksi transformatif yang menekankan mahasiswa sebagai pusat pembelajaran, 2) Kendala yang dihadapi oleh dosen maupun dosen meliputi aspek internal dan eksternal antara lain: kurangnya kompotensi dosen dalam mendesain materi di luar bidangnya, ketidakmampuan dosen dalam memenej intetkasi pembelajaran karena menggunakan e-learning dan kekurangcakapan dosen untuk momotivasi mahasiswa untuk lebih semangat dan beragirah dalam belajar kosakata Arab, mahasiswa tidak cukup kemampaun untuk berinteraksi dengan sumber belajar sehingga kurang minat dan motivasi dalam belajar.
\end{abstract}

Kata Kunci: Sumber Belajar, Kamus Dwibahasa, Mufradat, Hukum

\begin{abstract}
Arabic dictionaries for legal terms such as Mu'jam al-Qanun by Syauqi Dhoyf are used in Arabic learning at the Faculty of Law, Muhammadiyah Mataram University as a learning resource in mastering Arabic vocabulary in the field of law. The purpose of this study was to analyze the learning process of Arabic using a dictionary as a learning resource for students' mastery of Arabic vocabulary and the obstacles faced by lecturers and students of the Faculty of Law, University of Muhammadiyah Mataram. And as for this research method using a qualitative approach with the type of case studies and with data analysis Miles \& Huberman consists of three steps, namely data condensation, data exposure and drawing conclusions. And as for the research output, 1) The learning process of Arabic using a dictionary as a learning resource in mastering Arabic vocabulary emphasizes the existence of transformative interactions that emphasize students as a learning center, 2) Constraints faced by lecturers and lecturers include internal and external aspects, among others: lack of The potential of the lecturer in designing material outside their field, the inability of the lecturer to manage learning intetkation due to using e-learning and the lack of proficiency of the lecturer to motivate students to be more enthusiastic and passionate about learning Arabic vocabulary, students are not capable enough to interact with learning sources so that they lack interest and motivation in study.
\end{abstract}

Keywords: Learning Resources, Bilingual Dictionary, Mufradat, Law

\section{PENDAHULUAN}

Secara historis bahasa Arab pernah menguasai dunia berabad-abad lamanya dalam kekuasaan Dinasti Bani Umaiyah dan Dinasti Abbasyiah dan berandil besar dalam pengembangan peradaban dunia, namun pada memasuki era revolusi industry 4.0 dan era society 5.0 eksistensi bahasa Arab menjadi submayor setelah bahasa Inggris. 
Di Indonesia sendiri keberadaan bahasa Arab tetap eksis baik sebagai bahasa keagamaan maupun sebagai akademika terbukti dengan banyaknya kosakata bahasa Arab menjadi bahasa serapan dalam bahasa Indonesia seperti dalam bahasa hukum misalnya: hukum, dakwa, majlis hakim, amr, dll. Sehingga menjadi sebuah pertimbangan bagi beberapa fakultas hukum mengajarkan bahasa Arab kepada mahasiswanya.

Pembelajaran bahasa Arab di fakultas hukum lebih menekankan kepada penguasaan kosakata dalam istilah-istilah ilmu hukum daripada mengajarkan kemahiran berbahsa Arab (seperti istima', kalam, qiraah dan kitabah) ataupun ilmu bahasa arab seperti fonologi, morfologi, sintaksis, semantik, dan pragmatik.

Kamus dalam pembelajaran bahasa Arab merupakan kumpulan daftar kosakata bahasa Arab yang disertai dengan terjemahan, penggunaanya, dan perubahan kata, yang dapat difungsikan sebagai sumber belajar dan sebagai alat penunjang peningkatan kosakata bahasa Arab. Kamus yang sering digunakan dalam belajar bahasa Arab adalah kamus Mahmud Yunus disusun pada tahun 1972 dengan model dwi bahasa yaitu bahasa Arab dan bahasa Indonesia diurut berdasarkan sistem hijaiyah bagdadiyah.

Ada juga model kamus bahasa Arab yang khusus berkaitan dengan bidang tertentu seperti bidang ilmu hukum. Ilmu hukum (science of law/rechtswetenschap) adalah disiplin ilmu yang berdiri di atas kepribadian ilmunya sendiri (sui generis), oleh karenanya, ilmu hukum memiliki logikanya sendiri, yaitu logika hukum (logic of law/legal reasoning) dan untuk kebutuhan, kepentingan keberfungsian keilmuannya, maka ilmu hukum mempunyai bahasanya sendiri (language), yaitu bahasa hukum (law of language). Disiplin ilmu hukum keilmuannya dan struktur atau klasifikasi hukumnya beserta segala elemen- elemen pendukung sistemnya sarat dengan bahasa-bahasa hukum yang mengandung artikulasi karakteristik sebagai bahasa keilmuan hukum, sehingga untuk memahami disiplin keilmuannya dengan baik, maka harus menggunakan bahasanya sendiri yaitu bahasa hokum.

Salah satu fakultas yang mengajarkan bahasa Arab adalah Fakultas Hukum Universitas Muhammadiyah Mataram. Bahasa Arab menjadi matakuliah wajib dalam kurikulumnya dengan beban 2 sks, sejak berdirinya fakultas ini jauh lebih awal dari universitas, dimana bahasa Arab mulai diajarkan di semua fakultasnya pada tahun 2017 tapi masih bersifat matrikulasi. Keberadaan Matakuliah Bahasa Arab dalam fakultas ini dianggap sangat penting karena dapat menambah kemampuan mahasiswa dalam memahami istilah-istilah ilmu hukum dalam bahasa Arab, karenanya bahasa Arab yang diajarkan adalah Bahasa Arab dalam bidang hukum.

Penelitian lain mengungkapkan bahwa masih jarangnya penggunaan kamus khusus di lingkungan akademik, seperti kamus khusus bidang bisnis untuk mata kuliah Français des Affaires. Mahasiswa tidak memiliki atau mempersiapkan kamus khusus bidang bisnis. Padahal, sesungguhnya mahasiswa membutuhkan kamus khusus untuk menunjang pembelajaran, dan mereka memilih kamus khusus bidang bisnis dalam bahasa Prancis-Indonesia untuk digunakan dalam perkuliahan.

\section{METODE PENELITIAN}

Penelitian ini menggunakan pendekatan kualitatif, yang merupakan penelitian yang temuannya diperoleh berdasarkan paradigma, strategi, dan implementasi model secara kualitatif. Persfektif, strategi, dan model yang dikembangkan sangat beragam. Sebab itu tidak mengherankan jika terdapat anggapan bahwa qualitative research is many thing to many people.Dan adapun jenis penelitiannya adalah studi kasus, karena penelitian ini memiliki keunikan yaitu fakultas hukum sebagai fakultas umum mengajarkan bahasa Arab, dan bukan bahasa Arab pada umumnya tetapi bahasa Arab 
yang berkenaan dengan istilah- istilah dalam bidang ilmu hukum. Dan lenelitian ini peneliti menggunakan analsis data menurut Miles dan Huberman,yang memiliki tiga alur kegiatan yang terjadi secara bersamaan yaitu: kondensai data, penyajian data, penarikan kesimpulan/verifikasi.

\section{HASIL DAN PEMBAHASAN}

\section{Proses Pembelajaran Bahasa Arab Menggunakan Kamus Sebagai Sumber Belajar Dalam Penguasaan Kosakata Arab Mahasiswa Fakultas Hukum Universitas Muhammadiyah Mataram}

Proses pembelajaran bahasa Arab di Fakultas Hukum Universitas Mataram tidak bisa terlepas dari perencanaan atau persiapan pembejaran. Dalam pesiapan pembelajaran bahasa Arab di Prodi Ilmu Hukum dosen bahasa Arab lebih terdahulu menyiapkan rencana pembelajaran semester (RPS). Dalam RPS termaktub capaian pembelajaran bahasa Arab, sumber belajar, metode dan evaluasi pembelajaran Bahasa Arab. Hal ini apa yang disebutkan Anik Gufran kegiatan pembelajaran itu sebagai bentuk aktulisasi perencanaan yang tertulis di kelas dengan mentransfer ilmu pengetahuan dan pengalaman belajar di kelas. Dan hal terpenting dalam. Tujuan utama pembelajaran bahasa Arab di prodi ini adalah penguasaan kosakata hukum, dengan pertimbangan bahwa bidang hukum sebagai bidang profesi sehingga yang sangat dibutuhkan mahasiswa adalah kosakata bahasa Arab yang menunjang profesi mereka. Mereka kurang membutuhkan tujuantujuan lain seperti tujuan relegi seperti memahami agma Islam, tujuan akademik seperti mampu berbicara, membaca maupun mengarang menggunakan bahasa Arab.

Hal tersebut senada yang disebutkan Mahbub Secara teoritis, paling tidak ada empat orientasi pendidikan bahasa Arab yaitu: 1) Orientasi Religius, yaitu belajar bahasa Arab untuk tujuan memahami dan memahamkan ajaran Islam (fahm al-maqrû'). Orientasi ini dapat berupa belajar keterampilan pasif (mendengar dan membaca), dan dapat pula mempelajari keterampilan aktif (berbicara dan menulis). 2) Orientasi Akademik, yaitu belajar bahasa Arab untuk tujuan memahami ilmu- ilmu dan keterampilan berbahasa Arab (istimâ', kalâm,qirâ'ah, dan kitâbah). Orientasi ini cenderung menempatkan bahasa Arab sebagai disiplin ilmu atau obyek studi yang harus dikuasai secara akademik. Orientasi ini biasanya identik dengan studi bahasa Arab di Jurusan Pendidikan bahasa Arab, Bahasa dan Sastra Arab, atau pada program Pascasarjana dan lembaga ilmiah lainnya. 3) Orientasi Profesional/Praktis dan Pragmatis, yaitu belajar bahasa Arab untuk kepentingan profesi, praktis atau pragmatis, seperti mampu berkomunikasi lisan (muhâdatsah) dalam bahasa Arab untuk bisa menjadi TKI, diplomat, turis, misi dagang, atau untuk melanjutkan studi di salah satu negara Timur Tengah, dsb. 4) Orientasi Ideologis dan Ekonomis, yaitu belajar bahasa Arab untuk memahami dan menggunaakan bahasa Arab sebagai media bagi kepentingan orientalisme, kapitalisme, imperialisme, dsb. Orientasi ini, antara lain, terlihat dari dibukanya beberapa lembaga kursus bahasa Arab di negara-negara Barat.

Untuk mencapai tujuan pembelajaran penguasaan kosakata Arab dalam bidang hukum diperlukan sumber belajar atau media pembelajaran, seperti kamus bahasa Arab yang terdiri dari deretan daftar kosakata Arab dan terjemahannnya seperti kamus mukjam Alqanun yang disusun oleh asosiasi Bahasa Arab Mesir tahun 1999.

Hal tersebut berkaitan dengan kutipan Teguh pendapat beberapa ahli, bahwa Kamus Sebagai Sumber Belajar merupakan buku yang berisi seleksi kata yang disusun secara alfabetis dengan penjelasan makna dan informasi yang berkenanan dengannya dan dideskripsikan dalam bahasa yang sama atau berbeda. Dan kamus dianggap sebagai teks yang menyampaikan informasi yang umumnya disusun secara alpabetik. Lebih lanjut dia menyatakan bahwa kamus memberi informasi tentang unit kata dan mendeskripsikan 
bagian pengetahuan manusia yang berkaitan dengan bahasa. Hal itu yang membedakan kamus dengan ensiklopedi. Ada tiga hal yang dideskripsikan dalam kamus, yaitu karakteristik kata, karakteristik semantik, dan karakteristik kombinasioanal. Karakteristik kata mendeskripsikan cara pengucapan kata, pengejaan, dan cara pembentukannya. Karakteristik semantik mendeskripsikan makna yang dapat dimunculkan dari sebuah kata, termasuk informasi pragmatik dan penggunaan kata. Karakteristik kombinasional mendeskripsikan cara kata bergabung dengan kata yang lain.

Kamus Mukjam Alqanun yang digunakan di prodi Ilmu hukum kamus yang berisi istilah-istilah dalam bidang hukum menggunakan bahasa Arab dan arti katanya tertulis dalam bahasa Inggris. Dan dosen bahasa Arab menterjemahkan kedalam bahasa Indonesia. Melihat dari karakter kamus tersebut dikategorikan sebagai kamus dwibahasa seperti dijelaskan Abdul Chaer, bahwa berdasarkan penggunaan bahasa, Kamus bisa ditulis dalam satu atau lebih dari satu bahasa. Dengan itu kamus bisa dibagi menjadi beberapa jenis yaitu kamus ekabahasa (kamus menggunakan satu bahasa), kamus dwibahasa (Kamus ini menggunakan dua bahasa, yakni kata masukan daripada bahasa yang dikamuskan diberi padanan atau pemerian takrifnya dengan menggunakan bahasa yang lain), dan kamus aneka bahasa (Kamus ini sekurang-kurangnya menggunakan tiga bahasa atau lebih).

Peneliti dapat simpulkan bahwa sebelum proses pembelajaran bahasa Arab di prodi Ilmu Hukum dosen bahasa Arab menyiapkan perangkat pembelajaran yaitu RPS bahasa Arab dan menyiaplakn sumber belajar atau media belajar yaitu kamus dwibahasa bahasa Arab dan Inggris. Bobot matakuliah di prodi Ilmu hukum sebesar 2 sks ditempuh pada setiap semester 2 (genap), dan menjadi matakuliah wajib, yang diampu oleh beberapa dosen bahasa Arab dari prodi pendidikan bahasa Arab seperti Nasarudin, Ahmad Helwani, Husnan dan Nurjanah. Dan dalam proses pembelajarannya bervariasi tapi tetap penekanannya pada penguasaan kosakata dalam bidang hukum.

Proses pembelajaran melibatkan berbagai komponen antara lain: dosen bahasa Arab, mahasiswa, metode pembelajaran, materi pembelajaran dan media pembelajaran. Semua komponen tersebut berbalut dalam sebuah interaksi yang terpusat pada intetaksi antara pendidik dan peseta didik dalam menyampaikan isi pembelajaran dengan memamfaatkan sumber belajar. Jika pendidik dikategorikan sebagai sumber belajar maka interaksi terjadi antara sumber belajar dan peserta didik. Dan jika sumber belajar dianggap mewakili pembelajaran, maka interaksi terjadi antara pembelajaran dengan peserta didik. Dan begitu pula jika pembelajaran dapat mewakili kurikulum maka interkasi itu terjadi antara kurikulum dan peserta didik.

Hal ini dapat dikaji dengan beberapa pola interaksi dalam pemanfaatan sumber belajar di lembaga pendidikan, seperti pola tradisional pasif, pola tradisional aktif, pola interaksi multi arah, dan pola interaksi mandiri. Pola tradisonal pasif adalah pola interaksi pemelajar dengan sumber belajar dosen, di mana dosen dijadikan sebagai satu-satunya sumber belajar, tidak ada upaya tenaga pengajar mencari sumber belajar lain di luar dirinya (tenaga pengajar). Pola tradisional aktif adalah pola interaksi tenaga pengajar dengan sumber belajar, dimana peserta didik menjadikan tenaga pengajar sebagai sumber belajar utama, memang sudah ada upaya untuk menemukan sumber belajar lain secara parsial untuk melengkapi pesan-pesan yang diperoleh dari tenaga pengajar. Pola interaksi berbagai arah ini, adalah pola interaksi antara peserta didik dengan berbagai sumber belajar dan dimana peserta didik menempatkan seluruh sumber belajar dalam posisi setingkat. Pola interaksi mandiri adalah pola interaksi peserta didik dengan sumber belajar di mana peserta didik aktif berinteraksi secara mandiri dengan sumber belajar tanpa kontrol dari tenaga pengajarnya. Dalan istilah Miller dan Seller menyebutnya dengan 
interaksi transmisi yaitu interksi satu arah, interksi transaksi yaitu transaksi dua arah, dan interkasi transformasi yaitu taransaksi multiarah.

Untuk mengetahui model interkasi pembelajaran bahasa Arab menggunakan kamus dwibahasa dalam penguasaan kosakata Arab dalam bidang hukum, peneliti menjelaskan secara parsial komponen-komponen yang terlibat dalam peroses pembelajaran tersebut sebagai berikut.

Komponen Pertama Tenaga Pengajar/Dosen. Para pengajar bahasa Arab di prodi Ilmu Hukum hampir seluruhnya profesionalismenya dalam bidang pendidikan bahasa Arab terdiri dari magister dan doktor pendidikan bahasa Arab. Yang sudah memiliki kecakapan dan kompotensi mengajarkan bahasa Arab terlihat dari pengalaman belajar bahasa Arab selama sepuluh tahun sebagai modal besar dalam membuat pembelajaran bahasa Arab yang efektif dan menyenangkan dengan mevariasikan metode pembelajaran untuk menyampaikan materi sehingga mudah diterima oleh peserta didik. Tenaga pendidik memegang kunci kesuksesan pembelajaran bahasa Arab. Sesuai yang dikatakan oleh James M. Coper bahwa pendidik pembuat keputusan mulai dari perencanaan, pelaksanaan dan evaluasi dengan melakukan feedback terhadap masing-masing tahapan yang berorientasi pada perbaikan.

Proses pembelajaran bahasa Arab di prodi ini dilaku berbeda dengan tahun- tahun sebelumnya karena saat ini pelaksanaan pembelajaran hanya dilakukan via jaringan internet menggunakan aplikasi whatsapp group. Sedangkan pada semester sebelumnya pembelajaran bahasa Arab mahasiswa dan dosen berinteraksi langsung dalam sebuah kelas. Namun meskipun demikian pembelajaran bahasa Arab tetap dengan langkahlangkah pembelajaran yang normal ada pendahuluan, kegiatan inti dan penutup. Sebagaimana yang dikatakan oleh Mulyadi bahwa managemen kegiatan pembelajaran dapat diselenggarakan dengan tiga langkah yaitu kegiatan awal, kegiatan inti dan kegiatan penutup.

Dalam setiap tahapan tersebut peran dosen sangat penting dalam penentuan model pembelajaran yang akan digunakan dengan berorientasi kepada mahasiswa, terlebih bahasa Arab bagi mahasiswa prodi Ilmu Hukum hanya sebagai matakuliah penunjang, sehingga dosen harus membuat pembelajaran semenarik mungkin. Sebagaimana yang dikatakan oleh Tabroni bahwa guru mempunyai peran sebagai fasilitator membantu membuat kegiatan pembelajaran dalam bentuk yang baik.

Komponen Kedua, Metode/Strategi Pembelajaran. Dalam penentuan metode pembelajaran dosen harus lihai dalam penggunaan metode secara ekliktik, dengan mempertimbangkan psikologi peserta didik. Demikian juga dengan pendekatan yang digunakan baik pembelajaran berpusat pada peserta didik atau pembelajaran berpusat pada pendidik. Ada beberapa metode yang digunakan dalam pembelajaran bahasa Arab dalam mengajarkan kosakata, antara lain: metode ceramah, metode demonstrasi, dan lain-lain. Menurut Roy Killen pendekatan berbpusat pada pendidik menjadikan peserta didik hanya sebagai objek saja, peendidik meletakkan dirinya pada sumber belajar satusatunya, pembelajaran bergantung kehendak pendidik. Pendekatan ini melahirkan pembelajaran langsung dan pembelajaran deduktif. Sedangkan pendekatan berpusat pada peserta didik memberikan kesempatan yang luas dalam kegiatan pembelajaran karena mereka sebagai subjek pembelajaran sedangkan pendidik sebagai fasilitator dan pembimbing saja. Pendekatan ini melahirkan pembelajaran discoveri dan pembelajaran induktif.

Metode ceramah menjadi metode salah satunya yang digunakan dalam penguasaan kosakata bahasa Arab, diaplikasikan dengan menjelaskan kosakata Arab dalam bidang hukum terutama cara membacanya atau mengucapkannya dalam bentuk tulisan Arab 
dan tulisan latin karena ada beberapa mahasiswa yang tidak bisa membaca tulisan Arab. Dosen memberi contoh cara mengucapkannya dan menjelaskan makna kata tersebut jika makna kata bersifat abstrak, dan menunjuk bendanya jika makna kata itu bersifat kongkrit, dan pasti menggunakan bahasa Indonesia. Metode ini sesuai dengan langkah-langkah pengajaran kosakata yang disebutkan oleh Ismail Sinny dan Abdullah mengatakan bahwa sebaiknya mengajarkan kosakata melalui cara tahapan berikut: dengan cara menunjuk langsung pada benda (kosakata) yang diajarkan, dengan cara menghadirkan miniatur dari benda (kosakata) yang diajarkan, engan cara memberikan gambar dari kosa kata yang ingin diajarkan, dengan cara memasukkan kosakata yang diajarkan dalam kalimat, dengan cara memberikan padanan kata, dengan cara memberikan lawan kata, dengan cara memberikan definisi dari kosa kata yang diberikan. Apabila dari langkah-langkah tersebut di atas masih belum dipahami oleh siswa, atau kosakata yang tidak bisa diungkapkan dengan delapan langkah yang ada maka mengartikan kosakata ke dalam bahasa Ibu sebagai langkah yang terakhir.

Untuk mengaktifkan mahasiswa supaya lebih aktif dalam pembelajaran bahasa Arab untuk mengusai kosakata Arab dalam bidang hukum, dosen membagi mahasiswa menjadi beberapa kelompok dengan memberikan masing-masing kelompok membuat tugas kelompok yaitu mengetik koskata arab dan menterjemahkan kedalam bahasa Indonesia dan diperesentasikan secara bergantia dalam tiap pertemuan. Presentasi dilakukan dengan praktik mengucapkan kata, dimana masing-masing anggota kelompok membimbing satu kelompok di depan kelas membaca kosakata tersebut.

Hal tersebut sesuai dengan yang dijelaskan oleh Ahmad Fuad Effendy menjelaskan lebih rinci tentang tahapan dan teknik-teknik pembelajaran kosakata (al-Mufradât) atau pengalaman peserta didik dalam mengenal dan memperoleh makna kata (al-mufradât), sebagai berikut: 1) Mendengarkan kata. Ini merupakan tahapan pertama yaitu dengan memberikan kesempatan kepada siswa untuk mendengarkan kata yang diucapkan guru atau media lain, baik berdiri sendiri maupun di dalam kalimat. Apabila unsur bunyi dari kata itu sudah dikuasai oleh siswa, maka untuk selanjutnya siswa akan mampu mendengarkan secara benar. 2) Mengucapkan kata. Dalam tahap ini, guru memberi kesempatan kepada siswa untuk mengucapkan kata yang telah didengarnya. Mengucapkan kata baru akan membantu siswa mengingat kata tersebut dalam waktu yang lebih lama. 3) Mendapatkan makna kata. Pada tahap ini guru hendaknya menghindari terjemahan dalam memberikan arti kata kepada siswa, karena bila hal itu dilakukan maka tidak akan terjadi komunikasi langsung dalam bahasa yang sedang dipelajari, sementara makna kata pun akan cepat dilupakan oleh siswa. Ada beberapa teknik yang bisa digunakan oleh guru untuk menghindari terjemahan dalam memperoleh arti suatu kata, yaitu dengan pemberian konteks kalimat, definisi sederhana, pemakaian gambar/foto, sinonim (murâdif), antonim (dlid), memperlihatkan benda asli atau tiruannya, peragaan gerakan tubuh, dan terjemahan sebagai alternatif terakhir bila suatu kata memang benarbenar sukar untuk dipahami oleh siswa. 4) Membaca kata. Setelah melalui tahap mendengar, mengucapkan, dan memahami makna kata- kata (kosakata) baru, guru menulisnya di papan tulis. Kemudian siswa diberikan kesempatan membaca kata tersebut dengan suara keras. 5) Menulis kata. Penguasaan kosakata siswa akan sangat terbantu bilamana ia diminta untuk menulis kata-kata yang baru dipelajarinya (dengar, ucap, paham, baca) mengingat karakteristik kata tersebut masih segar dalam ingatan siswa.

Adapun pembelajaran bahasa Arab dalam penguasaan kosakata Arab dalam bidang hukum melalui aplikasi group whatsapp (WAG), dosen bahasa Arab menulis di WAG tersebut beberapa kosakata Arab dan terjemahannya beserta bacaan huruf latin. Kemudian dosen memberikan contoh cara membacanya dengan via audio WAG, setelah itu menyuruh mahasiswa menulis kosakata tersebut pada sebuah kertas dan membacanya 
lewat audio WAG juga. Hal ini dapat dikaitkan dengan Metode kognitif dengan ciri-ciri antara lain: 1) Teori ini berusaha untuk mengenalkan siswa tentang sistem bunyi, tata bahasa, morfologi dan dalalah Arabiyah sebagai bahasa kedua. 2) Pelajaran dimulai dengan menjelaskan kaidah dan diikuti dengan membuat contoh-contoh. 3) Latihanlatihan bisa dengan berbagai kegiatan kebahasaan dalam rangka pengembangan kompetensi komunikasi, yang sering dikenal istilah teori transformasi kreasi. 4) Menggunakan bahasa pembantu pada awal pembelajaran. Diawali dengan menjelaskan kaidah dan menjelaskan aturan-aturan bunyi bahasa Arab dengan ungkapan baru kepada peserta didik.

Komponen Ketiga, Sumber Belajar/Media Pembelajaran. Kamus bahasa Arab dapat dikategorikan sebagai sumber belajar dan media pembelajaran, yang berisikan materi pembelajaran. Kamus yang digunakan adalah kamus dwibahasa Mukjam Alqanun yaitu bahasa Arab dan bahasa inggris, kemudian dicari padanannya dengan istilah hukum yang sering digunakan dalam bidang hukum di Indonesia, karena ada tujuh prinsip dalam pemilihan pembelajaran mufradat, antara lain: 1) Frekuency, yaitu frekuensi penggunaan kata-kata yang tinggi dan sering itulah yang harus menjadi pilihan. 2) Range, yaitu mengutamakan kata-kata yang banyak digunakan di negaraarab maupun di Negara-negara non Arab atau di suatu negara tertentu yang mana kata-kata itu lebih sering digunakan. 3) Availability, mengutamakan kata-kata atau kosakata yang mudah dipelajari dan digunakan dalam berbagai media atau wacana. 4) Familiarty, yakni mendahulukan katakata yang sudah dikenal dan cukup familiar didengar 5) Coverage, yakni kemampuan daya cakup suatu kata untuk memiliki beberapa arti, sehingga menjadi luas cakupannya. 6) Significance, yakni mengutamakan kata-kata yang memiliki arti yang signifikan untuk menghindari kata-kata umum yang banyak ditinggalkan atau kurang lagi digunakan. 7) Arabism, yakni mengutamakan kata-kata Arab dari kata- kata serapan yang diarabisasi dari bahasa lain.

Dosen mengemas materi dengan baik dengan memperhatikan tujuan pembelajaran yang telah ditetapkan dalam rencana pembelajaran, seperti tujuan dari mempelajari mufrodat yaitu menambah perbendaharaan kosakata baru, melatih melafalkan dengan baik dan benar, memahami kosakata baru baik secara denotasi maupun konotasi dan mampu merangkainya menjadi suatu bahasa lisan atau tulisan.

Untuk memudahkan mahasiswa mempelajari kosakata Arab dalam bidang hukum menggunakan kamus Mukjam Alqanun, dosen bahasa Arab memberikan harakat atau bunyi vokal karena kamus tersebut belum punya harakat sehingga sulit dibaca oleh mahasiswa yang baru mengenal bahasa Arab. Kamus ini disusun berdasarkan susunan Hijaiyah Bagdadiyah. Tujuan penyusunan seperti ini supaya cepat mencari kata-kata yang diperlukan. Hal ini sesuai dengan metode penyusunan kata dalam kamus, yaitu ada dua cara: 1) pencarian kata secara alfabetis yang berupa huruf awal dari kata dasar dengan bantuan ilmu saraf, dan 2) secara artikulasi yang berupa huruf awal penyebutan kata. Pada umumnya enggunaan kamus cetak melalui pencarian kata secara alfabetis yaitu berupa huruf awal dari kata dasar.

Komponen Keempat, Peserta Didik.

Mahasiswa prodi Ilmu Hukum hampir keseluruhannya tidak pernah mengenal bahasa Arab, apalagi mereka yang termasuk nonmuslim, sehingga dosen bahasa Arab memiliki insting yang kuat dan telaten dalam mengajarkan bahasa Arab. Dosen bahasa Arab mengedepankan profesionalisme tanpa mengabaikan keadaan mahasiswa, dan mengedepankan proses dengan tanpa mengabaikan hasil belajar mahasiswa. Dalam pembelajaran peserta didik adalah komponen yang terpenting diantara kelompok lainnya. Pada dasarnya peserta didik adalah unsur penentu dalam proses belajar mengajar. Tanpa adanya peserta didik, sesungguhnya tidak akan terjadi proses pengajaran. Sebab peserta 
didiklah yang membutuhkan pengajaran dan bukan pendidik, pendidik hanya berusaha memenuhi kebutuhan yang ada pada peserta didik. Tanpa adanya peserta didik, pendidik tak akan mungkin mengajar. Sehingga peserta didik adalah komponen yang penting dalam hubungan proses belajar mengajar ini.

Jadi proses pembelajaran bahasa Arab menggunakan kamus sebagai sumber belajar dalam penguasaan kosakata Arab mahasiswa Fakultas Hukum Universitas Muhammadiyah Mataram menekankan adanya interaksi transformatif yang mengedepankan mahasiswa dalam mencapai tujuan pembelajaran membaur dengan sumber belajar sebagai cakupan dari komponen pendidik dan komponen pembelajaran lainnya.

\section{Kendala Yang Dihadapi Dalam Pembelajaran Bahasa Arab Menggunakan Kamus Sebagai Sumber Belajar Dalam Penguasaan Kosakata Arab Mahasiswa Fakultas Hukum Universitas Muhammadiyah Mataram}

Dalam sebuah proses tidak bisa terlepas dari berbagai kendala termasuk pembelajaran bahasa Arab menggunakan kamus sebagai sumber belajar dalam penguasaan kosakata Arab mahasiswa Fakultas Hukum Universitas Muhammadiyah Mataram, baik kendala yang dihadapi dosen maupun kendala yang dihadapi mahasiswa.

Pertama. Kendala yang dihadapi dosen dalam mengajarkan bahasa Arab menggunakan kamus untuk penguasaan kosakata Arab dalam bidang hukum menghadapi masalah dari aspek internal dan eksternal. Kedua aspek ini tidak bisa dipisahkan dan selalu saling berkaitan, seumpama hal yang berkaitan dengan kompetensi dosen dalam pemahaman materi dalam bidang hukum, terlebih kamus dwibahasa yang digunakan berbahasa Arab dan Inggris, sehingga sulit meyakinkan mahasiswa tentang makna kata yang diajarkan.

Kompetensi guru secara akademik, pedagogik, personal, dan sosial. Secara ideal, pengjar bahasa Arab selayaknya berasal dari latar belakang akademik jurusan atau program studi Pendidikan Bahasa Arab, atau sekurang-kurangnya dari jurusan. Bahasa dan Sastra Arab. Ada pula latar guru yang berasal dari lembaga pendidikan menengah semisal pondok pesantren atau madrasah, namun tidak memiliki jenjang kesarjanaan di bidang bahasa Arab. Kompetensi akademik kebahasaaraban sesungguhnya menjamin kemampuan pedagogik guru dalam mengajarkan bahasa Arab kepada para siswanya. Di samping itu, kompetensi personal dan sosial guru penting dalam rangka menunjang tugasnya mengajar dan membina siswa dalam bidang ilmu yang diajarkannya.

Dosen bahasa Arab berhadapan dengan tahapan-tahapan pembelajaran dari perencenaan, pelaksanaan, dan penilaian. Dalam tahapan-tahapan tersebut dosen bahasa Arab berjalan sendiri-sendiri tanpa ada arahan dari pimpinan prodi dan pimpinan fakultas sehingga mengajarkan bahasa Arab hanya sekedar memenuhi tugas mengajar saja tanpa ada rasa tanggung jawab akademik. Meskipun demikian Kausar dan Andriani mengungkapkan bahwa dosen sebagai salah satu kunci utama dalam keberhasilan pembelajaran harus mampu menggunakan berbagai metode pembelajaran. Proses pembelajaran harus lebih menarik perhatian mahasiswa, sehingga dapat berdampak pada peningkatan hasil belajar.

Dalam interkasi dosen dengan mahasiswa dalam pembelajaran, dosen berhadapan dengan psikologi mahasiswa yang kurang berminat belajar bahasa Arab, tidak termotivikasi dan kurang semangat dalam belajar bahasa Arab. Disinilah unsur pendidik sangat penting dalam memberikan motivasi, mendorong dan memberikan respon positif guna membangkitkan kembali semangat peserta didik yang mulai menurun. Guru bertindak sebagai alat pembangkit motivasi (motivator) bagi peserta didiknya. Guru 
Sebagai motivator hendaknya menunjukkan sikap antara lain; bersikap terbuka, membantu peserta didik agar mampu memahami dan memanfaatkan potensi yang ada pada dirinya secara optimal, menciptakan hubungan yang serasi dan penuh kegairahan dalam interaksi belajar mengajar di kelas, menanamkan kepada peserta didik bahwa belajar itu ditujukan untuk mendapatkan prestasi yang tinggi, sikap aktif dari subjek belajar mutlak diperlukan karena minat belajar itu seharusnya dapat tumbuh dari dalam diri subjek belajar sendiri dengan atau tanpa bantuan orang lain, melalui penekanan pemahaman bahwa belajar itu ada manfaatnya bagi dirinya.

Bobby De Porter dan Mike Hernacki menjelaskan ntuk menumbuhkan minat belajar mahapeserta didik, pendidik juga perlu menciptakan lingkungan belajar yang kondusif agar proses belajar di ruang kelas dapat berjalan sesuai dengan tujuan yang diinginkan dan menyenangkan. Dengan kata lain, peserta didik akan memiliki motivasi yang besar dalam mengikuti proses belajar mengajar di ruang kelas. Lingkungan belajar kondusif yang dimaksudkan adalah suasana santai dan nyaman, berinteraksi dengan lingkungan sekitar, mengembangkan dan mempertahankan sikap positif.

Dalam suasana pandemi covid 19 pembelajaran dislenggarakan via online sehingga dosen bahasa Arab merasa kesulitan dalam mengajarkan bahasa Arab terkait kurang memiliki pengalaman dalam elearning sehingga pembelajaran bahasa Arab berjalan seadanya, terlebih dosen kurang diberikan berimprovisasi dalam penggunaan aplikasi elearning tidak hanya sebatas penggunaan aplikasi whatsapp saja. Dalam hal ini guru hurus mampu beradaptasi dengan lingkungan sekitarnya ketika berhadapan dengan elearning dan kebijakan pengelola lembaga pendidikan.

Kedua. Kendala yang dihadapi mahasiswa dalam belajar bahasa Arab menggunakan kamus untuk menguasai kosakata Arab dalam bidang hukum tidak bisa terlapas dari faktor internal dan eksternal. Abu Ahmadi mengatakan bahwa masalah internal dan eksternal yang dihadapi para peserta didik tentunya ketika mereka belajar bahasa Arab di madrsah dan perguruan tinggi. Masalah internal merupakan berbagai masalah pembelajaran bahasa Arab yang muncul dari para peserta didik sendiri ketika belajar bahasa Arab, sedangkan masalah eksternal merupakan masalah yang berasal dari luar diri para peserta didik. Dengan kata lain, analisis problematikan pembelajaran bahasa Arab berangkat dari kondisi para peserta didik sebagai garis demarkasi untuk memetakkan masalah internal dan ekstrenal.

Mayoritas mahasiswa ini tidak memiliki kemampuan awal yang cukup untuk belajar bahasa Arab. Latar belakang mereka dari pendidikan umum yang tidak pernah belajar bahasa Arab dan baru mengenal bahasa Arab, dan beberapa dari mereka nonmuslim yang pastinya belajar bahasa Arab menjadi sesuatu yang baru. Dalam pembelajaran materi bahasa Arab, seorang pendidik mengetahui kemampuan awal bahasa Arabnya sangat penting karena untuk menentukan langkah berikutnya untuk pengembangan bahasa Arab, untuk menentukan langkah pembelajarannya, metode dan strategi pembelajarannya atau model pembelajaran bahasa Arab, sehingga dengan demikian, target dan tujuan pembelajaran bahasa Arab dapat diharapkan dengan maksimal dan tujuan pembelajaran bahasa Arab dapat tercapai. Namun apabila dari pertama kali, seorang pendidik tidak mengetahui kemampuan awal peserta didik maka dapat dikataka pembelajaran bahasa Arab akan mengalami kesulitan dan hambatan serius dalam pembelajaran dan evaluasinya.

Mahasiswa fakultas hukum memiki kecenderungan tidak berminat belajar bahasa Arab, tidak semangat saat proses pembelajaran dan bertanya-tanya untuk apa mereka belajar bahasa Arab padahal mereka jurusan hukum bukan jurusan agama. Apalagi mereka beranggapan bahasa Arab sebagai bahasa yang sulit. Seperti apa yang dipaparkan oleh Nasta'an bahwa rendahnya minat dan motivasi belajar serta adanya 
kecenderungan untuk "mengambil jalan yang serba instan" tanpa melalui proses kesungguhan. Sebenarnya, faktor penyebab kesulitan belajar bahasa Arab bukan sepenuhnya bersumber dari bahasa Arab itu sendiri (faktor internal sistem bahasa Arab) tetapi juga disebabkan faktor psikologis (minat, motivasi dan tidak percaya diri), juga kelemahan peserta didik dalam memilih pendekatan yang tanpa mempertimbangkan faktor-faktor psikologi, edukatif dan sosial kultural. Apalagi jika ditambah dengan lingkungan kelas yang tidak kondusif serta kesan negatif terhadap bahasa Arab.

\section{KESIMPULAN}

Kesimpulan penelitian ini yaitu:

1. Proses pembelajaran bahasa Arab menggunakan kamus sebagai sumber belajar dalam penguasaan kosakata Arab mahasiswa Fakultas Hukum Universitas Muhammadiyah Mataram menekankan adanya interaksi transformatif yang menekankan mahasiswa sebagai pusat pembelajaran dalam mencapai tujuan pembelajaran dengan mampu berinterkasi dengan sumber belajar yang menckup komponen pendidik dan komponen pembelajaran lainnya.

2. Kendala muncul dalam pembelajaran bahasa arab menggunakan kamus sebagai sumber belajar dalam penguasaan kosakata arab mahasiswa Fakultas Hukum Universitas Muhammadiyah Mataram, baik yang dihadapi oleh dosen maupun dosen meliputi aspek internal dan eksternal. Kedua kendala ini ibarat mata uang yang selalu berdampingan tidak dapat dipisahkan seperti kurangnya kompotensi dosen dalam mendesain materi diluar bidangnya, ketidakmampuan dosen dalam memanage intetkasi pembelajaran karena menggunakan elearning dan kekurangcakapan dosen untuk momotivasi mahasiswa suapaya semangat dan beragirah dalam belajar kosakata Arab. Demikian juga bagi mahasiswa bahwa mereka tidak cukup kemampaun untuk berinteraksi dengan sumber belajar sehingga minat dan motivasi mereka masih rendah.

\section{DAFTAR PUSTAKA}

Abdul Chaer. (2007) Leksikologi dan Leksikografi Indonesia.Jakarta: Rineka Cipta

Abdul Khair. (2012). Linguistik Umum, Jakarta: Rineka Cipta

Abdul Majid. (2007). Perencanaan Pembelajaran Mengembangkan Standar Kompetensi Guru. Bandung: Remaja Rosdakarya

Abdul Wahab Rosyidi. 2009. Media Pembelajaran Bahasa Arab, Malang: UIN MalangPress

Adisti Dwi Utami, Tri Indri Hardini, Yuliarti Mutiarsih.(2019). "Leksikografi Kamus Dwibahasa Prancis-Indonesia Khusus Bidang Bisnis", Linguistik Indonesia, Volume ke-37, No.1, 2019

Ahmad Falah. (2016) "Problem dan Tantangan Pembelajaran Bahasa Arab Pada Tingkat Madrasah” Arabia Vol. 8 No. 1, 2016

Ahmad Fuad Effendy. (2005)Metedologi Pembelajaran Bahasa Arab. Malang: Misykat 
Seminar Nasional Penelitian dan Pengabdian kepada Masyarakat

Universitas Sang Bumi Ruwa Jurai Tahun 2020

Anik Ghufran. (2003). Kurikulum Berbasis Kompetensi: Kajian Kritis Implementasi dan Implikasi. Yogyakarta: Laboratorium FSP Fakutas Ilmu Pendidikan UNY

Basse Wahida. (2017). “Kamus Sebagi Sumber Belajar: Kajian Terhadap Kamus Cetak Dan Kamus Digital”, Jurnal Al-Turats Vol. 11 No. 1

Besse Wahida. (2017). “Kamus Bahasa Arab sebagai Sumber Belajar”, At-Turats Jurnal Pemikiran Pendidikan Islam Vol. 11 No.1

Bisri Mustofa dan Abdul Hamid. (2011). Metode dan Strategi Pembelajaran Bahasa Arab Malang: UIN- Maliki Press

Djam'an Satori \& Aan Komariah. (2013). Metodologi Penelitian Kualitatif, Bandung: Alfabeta

Donald Ary. (2002). Introduction To Research In Education. Australia: Wadswort Thomson Learning

Elly Manizar. (2015). "Peran Guru Sebagai Motivator Dalam Belajar” Tadrib Vol. 1, No 2. 2015

Farid Helmi Setyawan \& Puput Eka Bajuri. (2018). "Penggunaan Kamus Olahraga Berbasis Android dalam Penguasaan Istilah Asing Bidang Olahraga",Pedagogia: Jurnal Pendidikan Volume. 7, No. 2, 2018

Hadari Nawawi. (2005). Metodologi Penelitian Bidang Sosial, Yogyakarta: Gajah Mada Press

Hendra Faisal. (2017). Metodologi Pembelajaran Bahasa Arab (Jakarta: Depag RI, 2006), Jenny Lilawati, "Analisis Pemanfaatan Sumber Belajar Dalam Proses Pembelajaran', Prosiding Seminar Nasional, Fakultas Ilmu Sosial Universitas Negeri Medan

Moleong, Lexy. (2015). Metodologi Penelitian Kualitatif. Bandung : Remaja Rosda Karya

Muhbib Abdul Wahab. 2017. "Peta Perkembangan Leksikografi Arab di Indonesia: Studi Kritis Atas Kamus Karya Mahmud Yunus", Arabi : Journal of Arabic Studies Vol. 2 No. 1, 2017

Muhbib Abdul Wahab, Epistemologi dan Metodologi Pembelajaran Bahasa Arab Jakarta: UIN Press, dalam Ubaid Ridlo, "Bahasa Arab Dalam Pusaran Arus Globalisasi: Antara Pesismisme Dan Optimisme", Jurnal Ihyaul Arabiyah, Vol 1 Edisi 2, 2015,

Nur Hizbullah \& Zaqiatul, "Mardiah Masalah Pengajaran Bahasa Arab di Madrasah Aliyah di Jakarta", Jurnal Al-Azhar Indonesia Seri Humaniora, Vo. 2, No.3,2014,

Nurul Qamar \& Hardiayanto Djanggih.(2017) "Peranan Bahasa Hukum Dalam Perumusan Norma Perundang-Undangan (Role Of Legal Language In Formulation Of Legislation Norms)", JIKH Vol. 11 No.3, 2017

Oemar Hamalik.(2004). Proses Belajar Mengajar. Jakarta: Bumi Aksara

Roy Killen, Effective Teaching Straategies: Lesson from Reseasrch and Practice, (Australia: Social Secience Press, 1998) dalam Rusman, Belajar Pembelajaran Berorientasi Standar Proses Pembelajran, (Jakarta: Kencana, 2017) 
Seminar Nasional Penelitian dan Pengabdian kepada Masyarakat Universitas Sang Bumi Ruwa Jurai Tahun 2020

Sa'diyatul Munawaroh. (2017). "Peningkatan Penguasaan Kosakata Bahasa Arab Melalui Metode Bernyanyi Pada Anak Usia Dini di RA Masitoh Salatiga Tahun Pelajaran 2016/2017”, Skripsi Institut Agama Islam Negeri Salatiga 2017

Supriadi. (2015). “Pemanfaatan Sumber Belajar Dalam Proses Pembelajaran”, Lantanida Journal, Vol. 3 No. 2, 2015

Syaiful Mustofa.(2011) Strategi PembelajaranNahasa Arab Inovatif.Malang: UIN Press

Volkan Cicek \& Hidayet Tok, Effective Use of Lesson Plans to Enhance Education in U.S. and Turkish Kindergarten thru 12th Grade Public School System: A Comparative Study, International Journal of Teaching and Education Vol. II No. 2,

Yulida, R. kausar. Andriani. (2016). "Penggunaan model pembelajaran penemuan terbimbing dalam meningkatkan aktivitas dan hasil belajar mahasiswa pada mata kuliah penyuluhan dan komunikasi pertanian". Mimbar Pendidikan: jurnal Indonesia untuk kajian pendidikan. Volume 1, Nomor 2, 2016 